CAPITAL FLOWS AND DOMESTIC AND INTERNATIONAL ORDER:

TRILEMMAS FROM MACROECONOMICS TO POLITICAL ECONOMY AND INTERNATIONAL RELATIONS

\author{
Michael Bordo \\ Harold James \\ Working Paper 21017 \\ http://www.nber.org/papers/w21017 \\ NATIONAL BUREAU OF ECONOMIC RESEARCH \\ 1050 Massachusetts Avenue \\ Cambridge, MA 02138 \\ March 2015
}

For helpful suggestions and comments we thank Barry Eichengreen, Jeffrey Frieden, Robert Keohane and Dani Rodrik. The views expressed herein are those of the authors and do not necessarily reflect the views of the National Bureau of Economic Research.

NBER working papers are circulated for discussion and comment purposes. They have not been peerreviewed or been subject to the review by the NBER Board of Directors that accompanies official NBER publications.

(C) 2015 by Michael Bordo and Harold James. All rights reserved. Short sections of text, not to exceed two paragraphs, may be quoted without explicit permission provided that full credit, including $\odot$ notice, is given to the source. 
Capital Flows and Domestic and International Order: Trilemmas from Macroeconomics to Political Economy and International Relations

Michael Bordo and Harold James

NBER Working Paper No. 21017

March 2015

JEL No. E4,E6,N1

\begin{abstract}
This paper explains the problem of adjustment to the challenges of globalization in terms of the logic underpinning four distinct policy constraints or trilemmas, and their interrelationship, and in particular the disturbances that arise from capital flows. The analysis of a policy trilemma was developed first as a diagnosis of exchange rate problems (the incompatibility of free capital flows with monetary policy autonomy and a fixed exchange rate regime); but the approach can be extended. The second trilemma we describe is the incompatibility between financial stability, capital mobility and fixed exchange[rates. The third example extends the analysis to politics, and looks at the strains in reconciling democraticLpolitics with monetary autonomy and capital movements. Finally we examine the security aspect and $\square$ look at the interactions of democracy with capital flows and international order. The trilemmas in shortldepict the way that domestic monetary, financial, economic and political systems are interconnected[with the international. They can be described as the impossible policy choices atthe heart of globalization. [Frequently, the trilemmas conjure up countervailing anti-globalization tendencies and trends.
\end{abstract}

\author{
Michael Bordo \\ Department of Economics \\ Rutgers University \\ New Jersey Hall \\ 75 Hamilton Street \\ New Brunswick, NJ 08901 \\ and NBER \\ bordo@econ.rutgers.edu \\ Harold James \\ History Department and Woodrow Wilson School \\ Princeton University \\ Princeton NJ 08544 \\ hjames@princeton.edu
}




\title{
Capital Flows and Domestic and International Order: Trilemmas from Macroeconomics to Political Economy and International Relations
}

\author{
Michael Bordo (Rutgers University and Princeton Institute of Advanced Study) and \\ Harold James (Princeton University)
}

Globalization - or the establishment of cross-national linkages - is rarely a simple unidirectional process. It brings major strains as quite different economic, social, and political systems adapt to each other's influences. This paper explains the problem of adjustment to the challenges of globalization in terms of the logic underpinning four distinct policy constraints or trilemmas, and their interrelationship, and in particular the disturbances that arise from capital flows. The analysis of a policy trilemma was developed first as a diagnosis of exchange rate problems (the incompatibility of free capital flows with monetary policy autonomy and a fixed exchange rate regime); but the approach can be usefully extended. The second trilemma we describe is the incompatibility between financial stability, capital mobility and fixed exchange rates. The third extends the analysis to politics, and looks at the strains in reconciling democratic politics with monetary autonomy and capital movements. Finally, we examine the security aspect and look at the interactions of democracy with capital flows and international order. The trilemmas in short depict the way that domestic monetary, financial, economic and political systems are connected with the international system. They can be described as the impossible policy choices at the heart of globalization. Frequently, the trilemmas conjure up countervailing anti-globalization tendencies and trends as we describe below.

In practice, as scholars investigating the exchange rate trilemma demonstrated, it is empirically hard to determine a pure policy stance in the trilemma: there are varying 
degrees of commitment to a fixed exchange rate regime, varying degrees of openness to international capital, and varying extents of monetary autonomy (Obstfeld Shambaugh Taylor 2005). In practice, there are thus almost no cases where policy is positioned at the corners of the trilemma, and practical policy stances fall somewhat in between the corner positions. The corners simply represent the boundaries of the possible. The discussion of the trilemma thus serves as a Weberian ideal type rather than an exposition of the world as it actually is. The same reservation applies to the other sorts of trilemma we identify in the paper: there is obviously neither pure financial stability nor pure instability, no absolute democracy, and no completely binding treaty organization or international system. There are always trade-offs. But identifying the choices as borders can identify problems and sources of tensions - and thus also help to establish what effective remedies might be. Finally, we think about the forms of cooperation - in regard to financial stability, and the building of agreements across borders - that may take the sharp edges off the trilemmas, move into a middle area, and reduce the likelihood of sudden and traumatic reversals and shocks.

\section{The macro-economic trilemma}

The first trilemma is undoubtedly the most familiar of the four issue-sets examined here. As Mundell (1963) formalized the point, free capital movements and a fixed exchange rate rule out the possibility of conducting independent monetary policy. Padoa-Schioppa (1982) reformulated this proposition as the "inconsistent quartet" of policy objectives by bringing in commercial policy, another central part of the globalization package: free trade, capital mobility, fixed or managed exchange rates, and monetary policy independence. In both the Mundell and the Padoa-Schioppa formulation, the impossible choice provided a rationalization for building a harder or more secure institutional framework for the securing of cross-border integration, and in 
particular they evolved this approach to deal with the problem of small or relatively small European countries. Both were major architects of the process of European monetary union. They justified this step of further integration on the grounds that the exchange rate was a useless instrument, the monetary equivalent of a human appendix or tonsils, that consequently could be usefully and painlessly abolished. Some countries, however, continued to regard the exchange rate as a useful tool for obtaining trade advantages.

The policy constraint following from free capital movements has recently been posed in a more severe form by Rey (2013), who shows that in a globalized world of free capital movements, monetary policy is limited even with flexible or floating exchange rates. A choice to have a floating exchange rate thus does not give a free pass to monetary policy. She identifies "an 'irreconcilable duo': independent monetary policies are possible if and only if the capital account is managed, directly or indirectly via macroprudential policies."This argument does not necessarily lend itself to the demonstration of the necessity of monetary union: if the aim is preserving national policy autonomy, a better choice is in controlling capital movements (as was envisaged in the 1944 Bretton Woods Conference, and provided for in the Articles of Agreement of the International Monetary Fund). Capital movement across borders - both through its attractions and the consequences of reversals - thus may fundamentally limit the scope for national monetary policy. Since the 2008 financial crisis, the articulation and elaboration of macro-prudential policies has become a way of trying in practice to limit or manage the extent to which capital may be mobile: the discussion of the monetary policy trilemma in consequence leads in a straightforward way to the discussion of financial policy issues.

Capital mobility however continues to be attractive. Borrowers - sometimes corporations, sometimes states - see capital inflows as a way of obtaining access to financial resources that they otherwise could not possess. In addition, the inflows may 
be linked to institutional innovation and governance reform. After waves of overborrowing, the costs may be clearer: capital flows, in the nice analogy of Stiglitz (1998), generate such large waves as to upset the delicate rowing boats of small countries afloat on the sea of globalization. But many participants in the process quickly forget the possibility of the large waves and tides.

Capital mobility

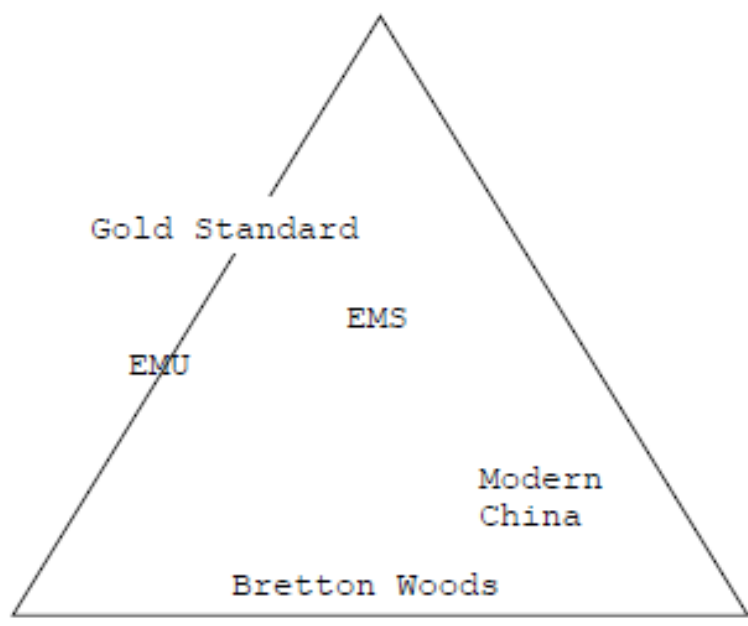

Fixed exchange rates

Monetary autonomy

The logic of the original Mundell trilemma thus points either in the direction of closer cooperation, including perhaps political arrangements that constrain domestic choices; or toward capital controls as a way of rescuing national policy autonomy. In the light of the gains that may be lost as a result of capital controls (and of an awareness of the necessarily incomplete character of capital controls, that makes them prone to evasion), the process of globalization points in the direction of a need for cooperation and coordination. 


\section{The financial stability trilemma}

The new formulation of the constraints on monetary policy follows from evidence of the enhanced volatility induced by the financial sector, and the proclivity of the world to lurch into credit cycles of large amplitude. Financial and particularly banking stability was incompatible with capital flows, when exchange rates were fixed and created misleading incentives for capital to move.

Understanding the character of the constraint requires reflection on the origins of the new financial instability. The formulation of the classical macro-economic trilemma says little about the sequencing of policy measures. The original Mundell formulation implies that policy formulation began in an idealized nineteenth century world, in which capital mobility and a fixed metallic exchange rate are taken as given, and central banks mechanically responded to gold inflows or outflows by loosening or tightening monetary policy. The third element, of a flexible monetary policy, is necessarily ruled out if the "rules of the game" are followed. Indeed, almost no nineteenth century analyst depicted monetary policy as a discretionary instrument. But this approach does not really even well describe nineteenth century reality, where most countries in fact engaged in considerable experimentation with the monetary standard (Bloomfield 1959); it was only in the last decades of the century that the gold standard became a nearly universal norm.

Why did the gold standard appear attractive? Countries went onto the gold standard, as later they engaged in fixed exchange rate arrangements, mostly in the hope that that would enhance credibility, provide a "good housekeeping seal of approval" (Bordo and Rockoff 1996), and consequently bring substantial capital inflows. Making the exchange rate stable became a tool that might be used to compensate for an inadequate availability of domestic capital. The beneficial effect of an inflow of foreign capital 
would only be realized if the domestic financial system started to intermediate the new flows; hence domestic financial expansion or the beginning of an expansive financial cycle was a consequence of the choice of regime.

This domestic financial expansion often (but not always) occurred on a rather inadequate institutional basis. Indeed financial underdevelopment and inexperience were frequently the flaws that the policy choice was intended to correct. In the underdeveloped financial system, there was little experience in managing credit allocation and in running banks. Countries wanted to go onto the gold standard in the nineteenth century, or to move to capital account openness in the late twentieth century, in order to build up their financial institutions. A result of the financial inflows was thus often a rising vulnerability as the domestic institutions were rather fragile. But as long as the inflows continue, there is often a false confidence that additional capital is indeed producing a more stable and mature financial system.

There was a learning process about finance that set in after the capital inflows, and it clearly took time for countries to adapt their institutions to the capital inflows and risks of crises. But in many cases, countries failed to adapt efficiently and the capital flows simply reinforced existing rent-seeking and corrupt institutions (Calomiris and Haber 2014). In these cases, capital inflows increased rather than decreased the vulnerability.

The interplay of international capital movements and weak banking system in emerging markets has provided a constant source of major international financial crises. Well known examples include the United States in the 1830s, Argentina in the late nineteenth century, Central Europe in the 1920s, some emerging Asian countries in the 1990s, and Southern Europe in the 2000s. In many, but not all cases, the surge of capital also produced fiscal crises in the aftermath of an over-issue of state debt, driven by bailouts of insolvent banks or by guarantees (explicit or implicit). There was often then an attempt to compensate for financial stability by providing government guarantees, 
which in the end involved unfulfillable promises and made the financial instability greater.

In the late 1830s U.S. states went on a borrowing spree. At the same time, President Andrew Jackson launched a Bank War, in the course of which he vetoed the rechartering of the Second Bank of the United States (a powerful institution that controversially combined central banking with commercial banking functions), but also encouraged other banks to seek charters. The result was successful in achieving Jackson's immediate objective, in that it decentralized credit. But then the new banks (the "pet banks" as they were disparagingly termed) immediately started to expand lending, above all to the states and the political elites that had facilitated their establishment. The upshot was an orgy of bank credit to individual states, often structured in a complex way so that debt securities could be repackaged and sold on foreign markets. After bank failures in 1839, the states themselves extended credit directly, and eventually, after 1841, many defaulted (Wallis Sylla Grinath 2004).

At the end of the nineteenth century, the 1890 bankruptcy of Argentina triggered a rethinking of how capital flows were handled. Argentina was at the time the world's largest borrower in terms of share of GDP, with "some of the most spectacular capital inflows of the history of the world economy" (Taylor 2003, p. 178). A modern calculation suggests that Argentina imported capital amounting to $18.7 \%$ of its GDP between 1870 and 1889 (Flandreau and Zumer 2004); and by the 1880s, Argentina accounted for almost half of British foreign lending (Ford 1963; Mitchener and Weidenmier 2006). The availability of foreign money prompted a fiscal expansion and overstretch. In parallel, the 1887 Law of National Guaranteed Banks is a fine example of a law that appears to constrain banking activity and thus guarantee stability, but in practice led to a bank glut. Under the law, banks were required to buy National Gold Bonds issued by the Treasury as a requirement for note issue. The banks raced to borrow as much as they could on foreign markets, mostly in London, and deposited the 
gold with the Treasury. They could then use the banknotes as a basis for domestic credit expansion. After 1887, money creation surged (Cortes Conde 1989, della Paoloera and Taylor 2007). Price increases made Argentina uncompetitive, tax revenue fell off, and a debt crisis erupted in 1890.

Banks in Central Europe had their capital largely wiped out by hyper-inflation in the aftermath of the First World War. Stabilization involved returning to the gold standard, in the expectation that this would make financially and fiscally stricken countries the recipients of capital inflows. In the course of postwar inflation and hyperinflation, Central European bank capital had been destroyed; and in the stabilization of the mid1920s, banks began with severely reduced levels of capital relative to the prewar position. They found it expensive to raise new capital, and their new lending in consequence occurred on a very thin capital basis. They also found it much harder than before the War to attract retail deposits, and they funded lending in consequence with interbank credit - both from domestic sources and from international borrowing, largely from the United States (Kindleberger 1973; Eichengreen 1992). The external source of finance drove banking expansion in Germany and elsewhere It was only at the height of the credit boom that bank loans relative to GDP reached prewar levels (which were high in an international comparison). Paradoxically, this reflection on catch-up offered one ground for creditors to believe that their claims might be secure (Balderston (1993)). The vulnerability was increased by the persistence of a German prewar tradition of thinking of the central bank as a lender of last resort, and a belief that the government would ultimately step in to guarantee debt. That represented the most fundamental flaw in the domestic policy regime. The safety net provided by the Reichsbank allowed a thinner capital basis, and gave a misguided confidence to both the banks and their creditors (James (1998)). The expansion of borrowing by Central European banks occurred in an informational or statistical fog (BIS $(1932,1934))$. The vulnerability of the banks - in a banking crisis that accompanied a currency crisis - was 
a major cause of the financial collapse and of the reversal of capital flows (James 1986, Schnabel 2004).

The 1997 Asia crisis had its origins in a financial liberalization, when in 1993 the Thai government established the Bangkok International Banking Facility, allowing a substantial number of domestic and foreign banks to operate an international banking business. They engaged in heavy foreign exchange borrowing, which they then used to expand credit domestically. Again there were implicit guarantees of the foreign currency exposure of the banks, in that it was correctly believed by the foreign creditors that the borrowing banks were too important to fail (Dooley 2000; Krugman 1999).

The introduction of the Euro in 1999 prompted a surge of capital into southern and peripheral Europe. As in Asia in the 1990s, there were large current account deficits, and as in East Asia, these were in some cases exclusively private sector imbalances, with the public sector fiscal position appearing strong in countries with a borrowing surge (notably Ireland and Spain). There was also a great confidence that the inflows were modernizing and building more resilient financial and indeed political systems. Investors also assumed that there should be some implicit guarantee. As a prominent Greek politician, Yiannos Papantoniou explained, in 2005, “Greece completed a cycle of substantial modernization over the previous decade. Overcoming the economic instability and stagnation of the previous era, it managed to consolidate its finances, reduce inflation, accelerate growth and promote structural changes conducive to a friendlier environment for enterprise and investment." (Lynn 2011, p. 54) Political scientists spoke of Greece's Europeanization and modernization that made it morph into a "first-rate liberal democracy with a good economy." (Kalaitzidis 2009, p. 1)

The general lessons from these historical episodes is that liberalized financial systems weaken financing constraints, thereby providing more room for the build-up of financial imbalances (Borio James Shin 2014). Not every surge of foreign lending had 
the same effect: Canada was able to digest capital inflows, and sustain a long current account deficit in the nineteenth century, without incurring financial fragility.

The most extreme cases of the damaging effects of capital inflows occur in fixed exchange rate regimes (the nineteenth century gold standard, 1920s Europe, the Asian boom of the 1990s) or in a monetary union (in Europe in the 2000s). In consequence, it is sometimes argued that a flexible exchange rate would curb the excesses, as capital inflow would bring an exchange rate appreciation that lowered trade competitiveness and reduced the attractiveness of new inflows. But this approach would block off many of the beneficial effects that borrowers expected to obtain from the inflow of capital.

When matters turned out badly, the problem was discussed as an issue of the appropriate sequencing: that it would have been better to build stronger domestic institutions first before seeking mechanisms to encourage capital inflows. There should be no opening of the capital account before a deepening of the domestic financial system had taken place. Otherwise, the inflow of new money risked creating financial imbalances. But this point misses the fundamental original calculation that the domestic system would never develop adequately on its own, and that it needed the resources from the outside. In a sense, then, the financial instability is frequently built into the development process. 


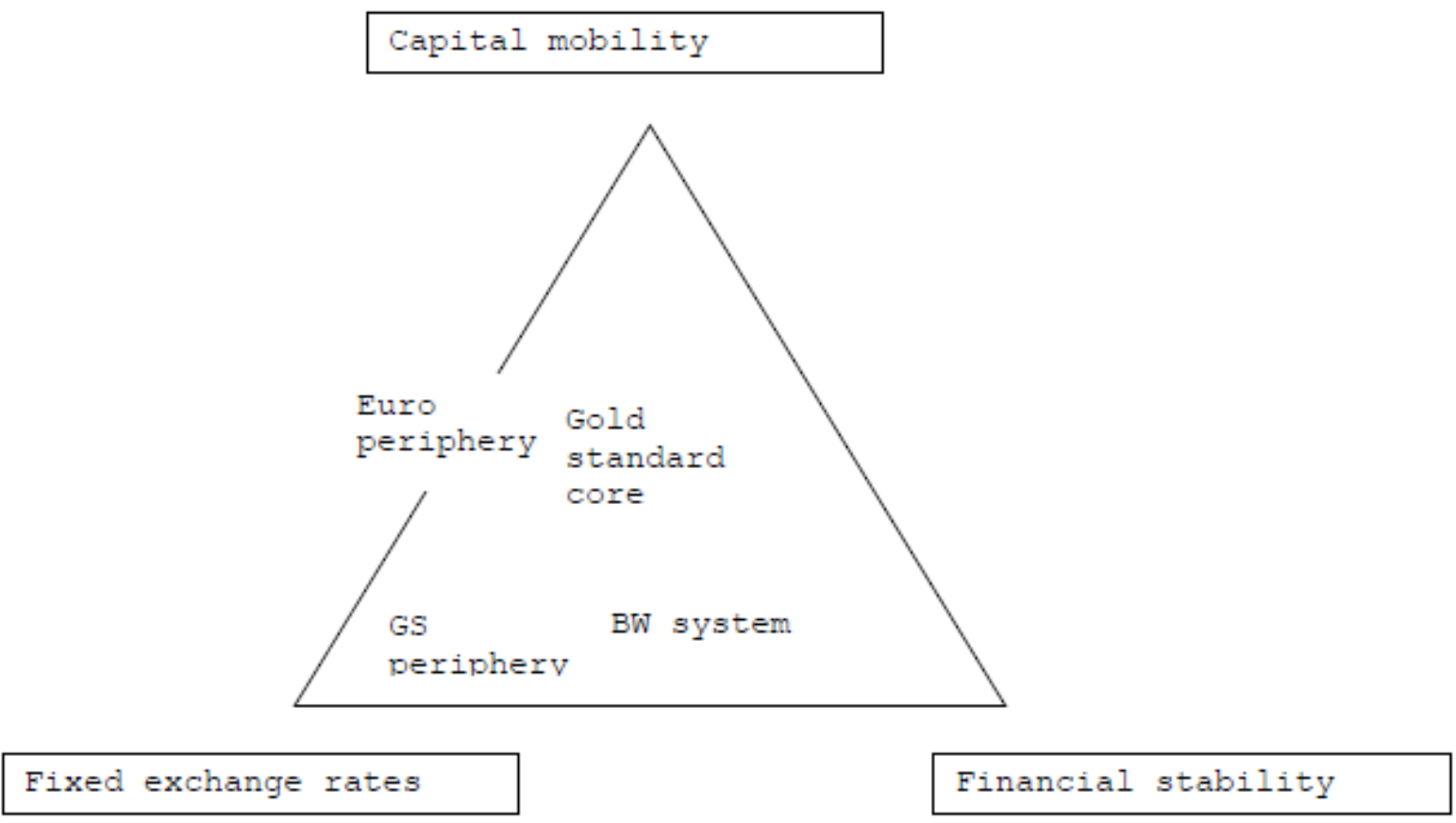

Opening the capital account in a fixed exchange rate regime is hard to reconcile with financial stability. This logic provides the second trilemma.

\section{The political economy trilemma}

After a period of financial opening, the consequent development of financial imbalances may strain the political system. States (whether they are autocracies or democracies) initially like the benefits that flow from open capital markets. Democracies, in which governments are responsive to short term demands of voters, are also likely to want to set monetary policy independently. They need to work out a trade-off between present monetary autonomy and the ability to attract inflows. In addition, both policies have time consistency problems of a different character. First, the monetary stimulus will only bring immediate benefits if it is unanticipated; if there is an expectation that the 
behavior is repeated, agents will build the future into their responses to the stimulus. The stimulus relies on the non-continuation of the policy. Second, by contrast, the capital inflows may also bring short term effects, but if they are abruptly curtailed, investment projects will be uncompleted and repayment will be problematical. The benefits rely on the expectation that the flows will continue. But states, especially democratic states, find it hard to commit to policies that will really lock in the institutional basis on which the long term inflows can occur: there is much rather an incentive to derive simply short run advantages (such as those following from monetary stimulus), and leave longer term problems to successor governments.

And the problems arising when capital flows end or reverse can be terrible. The immediate transmission mechanism is financial and economic. The collapse of unstable financial structures has an immediate and severe economic effect. The effects may include most or all of the following features: bank collapses; withdrawal of bank credits; rise in bankruptcies; collapse of prices; rise in unemployment. These effects were presented in a celebrated article by Irving Fisher (1933) as debt-deflation. In Fisher's presentation there was no lender of last resort but even with a LLR and deposit insurance, guarantees and rescues can lead to fiscal crises.

When and while the inflows continue, and the financial imbalances build up, the system looks as if it is politically attractive and stable. Indeed, political parties will often make compromises to support governments that can promise the institutional reforms needed to allow the inflow of capital to continue. Warning against the potentially deleterious effects is a business that is unattractive, and left to outsiders, who make Cassandra-like prophecies. The insiders who benefit from the inflows can combine to ridicule the Cassandras.

However, when the financial strains appear, and with them the costs of the engagement with openness, political parties no longer wish to be associated with the consequences. 
Voters will blame the parties that have been associated with power for their past mistakes; and they flock to parties that define themselves as being against the system. In modern parlance, these are often described as populist. The populist parties may be on the left or on the right; and in fact, most anti-system parties combine elements of a left and a right wing critique of the system they are trying to overthrow. The left wing critique is that the burden of crisis adjustment of incomes and wealth falls unequally and unfairly on the poor. The right wing critique emphasizes that the adjustment works to the benefit of foreign creditors and represents a derogation of national sovereignty. These different arguments are obviously really not that opposed to each other, and can and are easily combined. In these circumstances, the democratic principle is simply recast as a defense of national sovereignty.

Examples of the disintegration of traditional party systems in the aftermath of severe financial turbulence can be found in twentieth century history, but also in the contemporary Euro-crisis. The Great Depression produced a disintegration of democratic systems in central and eastern Europe and in Latin America. Probably the iconic case of democratic failure is that of Weimar Germany, which had a constitution and political system that had been carefully designed by distinguished political theorists (notably Max Weber and Hugo Preuss) so as to be as perfect as possible a reflection of popular voting preferences: thus there was both a direct election of the President and a proportional representation so designed that there would be no "lost" votes. The parties committed to democracy progressively lost voting shares; and parties associated with government lost especially badly. By the time of the Great Depression, both the center-left (the Social Democratic Party) and the center-right (the Democratic Party and the German People's Party) had lost significantly, and were no longer capable of commanding a parliamentary majority. In terms of policy, the governments could do little, and their policy options were profoundly limited (Borchardt 1991). 
The disintegration of system parties in the face of economic constraints is also a key element in the modern financial and political crisis in Europe. In Greece, the centerright New Democracy was defeated in elections in October 2009, and succeeded by the center-left Pasok (with 43.9 percent of the vote). Pasok was then discredited by its negotiations with creditors and by the wavering of Prime Minister George Papandreou on whether to hold a referendum on the terms of the plebiscite. After new elections in May 2012 (which were inconclusive), and then June 2012, New Democracy returned to head a coalition government. The center-right had only 29.7 percent of the vote it depended on Pasok, which had collapsed to 12.3 percent, and which had been squeezed into third place by the radical left populist party Syriza. In January 2015, New Democracy had shrunk to 27.8 percent and Pasok to 4.7 percent, and Syriza with 36.3 percent could form a government with a populist right wing party (Independent Greeks, 4.8 percent of the votes). In Spain, in elections in November 2011, the socialists who had been in government in the first part of the financial crisis were punished with a fall in the vote from 43.9 to 28.8 percent, and power changed to the center-right Popular Party. But by 2015 that too was threatened by a populist left party, Podemos, which treated Syriza as a model. In Italy, in 2013 elections, the party of Silvio Berlusconi, which had formed the government in the first phase of the crisis, with 29.1 percent narrowly lost to the center left (29.5 percent); by 2014 in European Parliament elections Berlusconi's movement was in third place with only 16.8 percent of the vote, and a populist leftist movement headed by a clown, Beppe Grillo, had 21.2 percent of the vote (it had done even better in the 2013 elections to the Italian parliament). The technocratic prime minister, Mario Monti, who had stepped in when Berlusconi's government collapsed under international pressure, had founded a new political party (Civic Choice) but only got 8.3 percent of the vote in 2013 - a result that looked similar to those of the liberal parties in the late years of Weimar Germany. 
Even if the anti-system parties do not succeed in gaining majorities, their enhanced support and electoral support pushes the old or system parties to take a less accommodating and a more radical stance.

Politicians' only way of explaining their position in hard times, when they demand sacrifices of their voters, is often to say that their hands are tied. While that may be a plausible argument for very small countries, the larger the country, the less compatible this stance is with the idea of national sovereignty. Consequently, the demand for an enhanced national sovereignty appears as a frequent response to setbacks, and even small countries may rebel. As Greece's flamboyant radical finance minister Yanis Veroufakis put it in 2015: "The notion that previous Greek governments signed on the dotted line on programmes that haven't worked, and that we should be obliged to just follow that line unswervingly, is a challenge to democracy." 1

The demand for national policy autonomy affects the policy equilibrium that arises out of Trilemma 1. Reflection on time-consistency problems, when monetary independence might lead to a short term stimulus but entail on a longer time horizon ultimately costly effects, led to the conclusion that an independent monetary policy was in fact undesirable. Monetary independence would lead to political pushes to manipulate monetary policy for short term advantages without providing any long-term gains. The Mundell trilemma in these circumstances pointed in the direction of constraining national monetary autonomy. If the outcome of a likelihood of a turning to a more national monetary policy is known in advance, it would influence investors' calculations. They would see commitment to a gold standard or fixed exchange rate regime as ultimately lacking in credibility.

1 Financial Times, February 2, 2015, "Greece finance minister reveals plan to end debt stand-off." 
The possibility of such a reversal looked less likely in the nineteenth century, at the time of the classic gold standard. At that time, investors in fact often made the argument that the extension of constitutional rights was more rather than less likely to protect investors' rights. The phenomenally successful banking house of Rothschild consistently pressed for political reforms, imposing a sort of political conditionality (Ferguson 1999). The people who were represented in parliaments were on the whole creditors: making policy dependent on their assent meant ruling out the possibility of an expropriation of creditors. As the franchise was extended, parliaments however no longer reflected a preponderance of creditors: they came more and more to represent groups that benefited from state transfer payments. Such payments stood as alternative claims on the public purse to the requirement to service debt. The experience of the first major cycle of the political process in which democracy turned against creditors led Polanyi (1944) to make the famous argument that the gold standard (and by implication analogous regimes) were impossible in a democratic age.

The memory of the politics of the turning against creditors during the Great Depression faded with the credit supercycle that emerged slowly in the second half of the twentieth century. The argument then began to resurface again primarily in arguments about the compatibility of globalization with democracy in emerging markets (Eichengreen 1996). Rodrik (2000 and 2007) formulated the point in this way as a general argument about the incompatibility of hyperglobalization, democracy and national self-determination: “democracy, national sovereignty and global economic integration are mutually incompatible." He presented the European Union as the best template of a new form of global governance with supranational rulemaking (Rodrik 2011). After the Great Financial Crisis, the same problems and policy dilemmas appeared in rich industrial countries, and globalization appeared vulnerable again.

Democratic politics can be thought of as evolving two sorts of operation: the formulation of laws based on general principles of conduct, and redistribution of 
resources. The capacity to redistribute is limited if there is a large cross-border mobility of factors of production: capital is most obviously mobile, and escapes if rates of capital taxation are too high; but the same process may also hold true in the case of taxation of high incomes, and income earners will try to operate in a different national and tax setting. Even the capacity to formulate general laws may be limited, in that incompatible principles in different countries may produce anomalies or loopholes, and possibilities for forum-shopping.

Politicians are often painfully aware of the restraints. Jean-Claude Juncker, the veteran prime minister of Luxembourg and current president of the European Commission formulated the constraint in the following way: "Politicians are vote maximisers... for the politician, the Euro can render vote-maximising more difficult, as a smooth and frictionless participation in the monetary union sometimes entails that difficult decisions have to be undertaken or that unpopular reforms have to be initiated." (Marsh 2011, p. 269) 


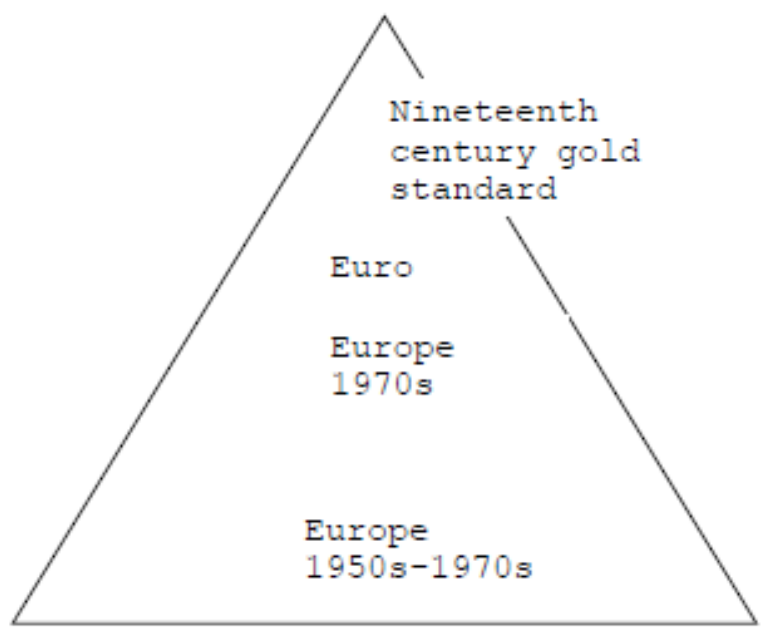

The third trilemma may be formulated as the incompatibility of capital flows, independent monetary policy, and democracy. It poses a severe problem for people who believe that a major area of policy in a modern state should be capable of being decided by a democratic process.

\section{The international relations trilemma}

Democracies like international order, when it helps them to attract beneficial capital inflows. But both the capital mobility (as we have seen) and the limits imposed by international order narrow the scope for democratic politics.

The tying hands argument in regard to ensuring that democratic decisions were compatible with a longer term framework of stability was frequently presented in the form of treaties or security arrangements. Often the reassurance that creditors needed 
in order to convince them to lend was political rather than simply a monetary commitment mechanism (such as participation in the gold standard, an exchange rate mechanism, or the monetary union). Alliance links offered to investors the security that creditor governments would put pressure on banks to continue lending, and hence reduced the likelihood of sudden stops. The search for credibility might lead to a security commitment, and countries would seek ties with powerful creditor countries because of the financial benefits. This kind of argument about the security bulwark that locks in capital movements applies to both democratic and non-democratic regimes.

In addition, in democratic societies the redistributory impulse generated by the political process may - especially when the limits of domestic redistribution become apparent translate into a wish to redistribute the resources of other countries. The burden of an unpleasant adjustment could conceivably be shifted onto other people - who are outside the national boundary and thus outside the political process. It is this impulse (Let the others pay!) that is restrained by treaties and security commitments. An alliance system, or closer political union (as in modern Europe) helps to restrain destabilizing democratic impulses, in which one country's democratic choices are confronting the voting preferences of other democracies.

Like all the other mechanisms involved in the various trilemmas, the security relationship too thus may reverse. If the security regime was severely challenged, the gain in credibility would no longer look attractive. And if capital flows reversed, or even if financial fragility appeared, there would be fewer gains from participating in the international order. Potential borrowers that had locked themselves into security or other cooperative arrangements would then be tempted to defect.

The story of how diplomatic commitments enhance credibility is especially evident in the well-known case of Russia (a case obviously of non-democracy or autocracy locking into international security commitments). The beginning of the diplomatic 
rapprochement of Russia with France in 1891 was accompanied by a French bond issue, which the supporters of the new diplomacy celebrated as a "financial plebiscite" on the Franco-Russian alliance. Russia survived a sharp contraction in 1900-01, as well as a political crisis with war and revolution in 1905, with no default. It raised new money immediately after the revolution of 1905. By 1914, almost half of the $1733 \mathrm{~m}$. ruble Russian government debt was held abroad, and four fifths of that was in French hands, with the UK holding 14 percent. The diplomatic, military and financial calculations were intricately tied together, and were skillfully used by Russia as a way of locking in the creditors politically and economically (Siegel 2014).

In imperial systems (which again are non-democratic), the imperial security umbrella, coupled with the extension of legal principles from the metropol, functioned in a similar way and reassured investors that the country was capable of sustaining greater debt levels. The effect has been attributed to imperial order, but it is hard to determine whether it is more due to the effects of good policy, imposed as a result of reform minded administrators, or of the power of the empire to compel repayment. (Ferguson and Schularick 2006). In the aftermath of some crises, the imperial system simply expanded to swallow up bankrupt debtor entities: well known example are Egypt in 1875, or Newfoundland in 1933. But even very big and powerful political units sought financial shelter via an embrace by financially stronger powers. In an extreme example in early 1915, the Russian government suggested a fiscal and political union with France and UK to allow it continued access to credit markets (Siegel 2014).

When capital dries up, incentives to make international commitments also disappear. A good case of the consequences of the logic of the reversal, when the international system no longer promises large financial gains, appears in interwar Italy. When the capital market was open in the 1920s, the fascist dictatorship of Benito Mussolini stabilized its currency and entered a fixed exchange rate regime (the quota novanta). Mussolini also moderated his foreign policy, and suppressed any proclivity to political 
adventurism. When the international financial system broke down with the international banking crisis of 1931, there were no longer any financial benefits that could follow from foreign policy restraint. Mussolini started to reorient his policy toward imperial expansion. In response to the Great Depression, Hitler proposed exactly such a policy outcome: Germany should break with the international constraints and enrich itself at the expense of the neighboring countries. The reversing of the gains that follow from security commitments is thus likely to be associated with a backlash against democratic politics.

There are more modern variants of the same process. After private capital flows in Europe from north to south halted in 2008, many southern Europeans lost their enthusiasm for European integration and turned against both the Euro and the European Union.

The case of modern Russia is even more striking. Until 2008, President Putin initially appeared as a rather pro-western, modernizing leader who sought an engagement with the world economy - that included access to capital markets in order to allow Russia to develop. Before 2008, a logic of global capitalism received Russian acquiescence. Russia needed to cooperate with global multinational companies in order to build up an economy based on raw material and energy production, but also on technologies that developed the raw materials.

But in 2007-8, Russia's strategy changed. On the eve of the financial crisis, Putin had presented a new front to the world when he spoke to the annual Munich Security Conference about the new power potential of the BRICs as an alternative to what he dismissed as an arbitrary "unipolarity". His audience was shocked and surprised, and many at the time took the speech as evidence of an insecurity or irrationality. In contrast, as the financial crisis spiraled out of control, Putin reached the conclusion that he had been prophetic. After the crisis, if one follows power logic instead of the logic of 
economic growth, there was no longer so much to be gained from global markets.

Instead, the best game in town was to cooperate with other countries with a more statecentered capitalism, notably China.

In a world in which capital links do not bring mutual gains, democratic politics in each country look as if they are targeted against other countries. Veroufakis again provides a striking instance of this analysis when he referred to lessons from ancient Greece and its warring states: "Sometimes the larger, powerful democracies undermined themselves by crushing the smaller ones." 2

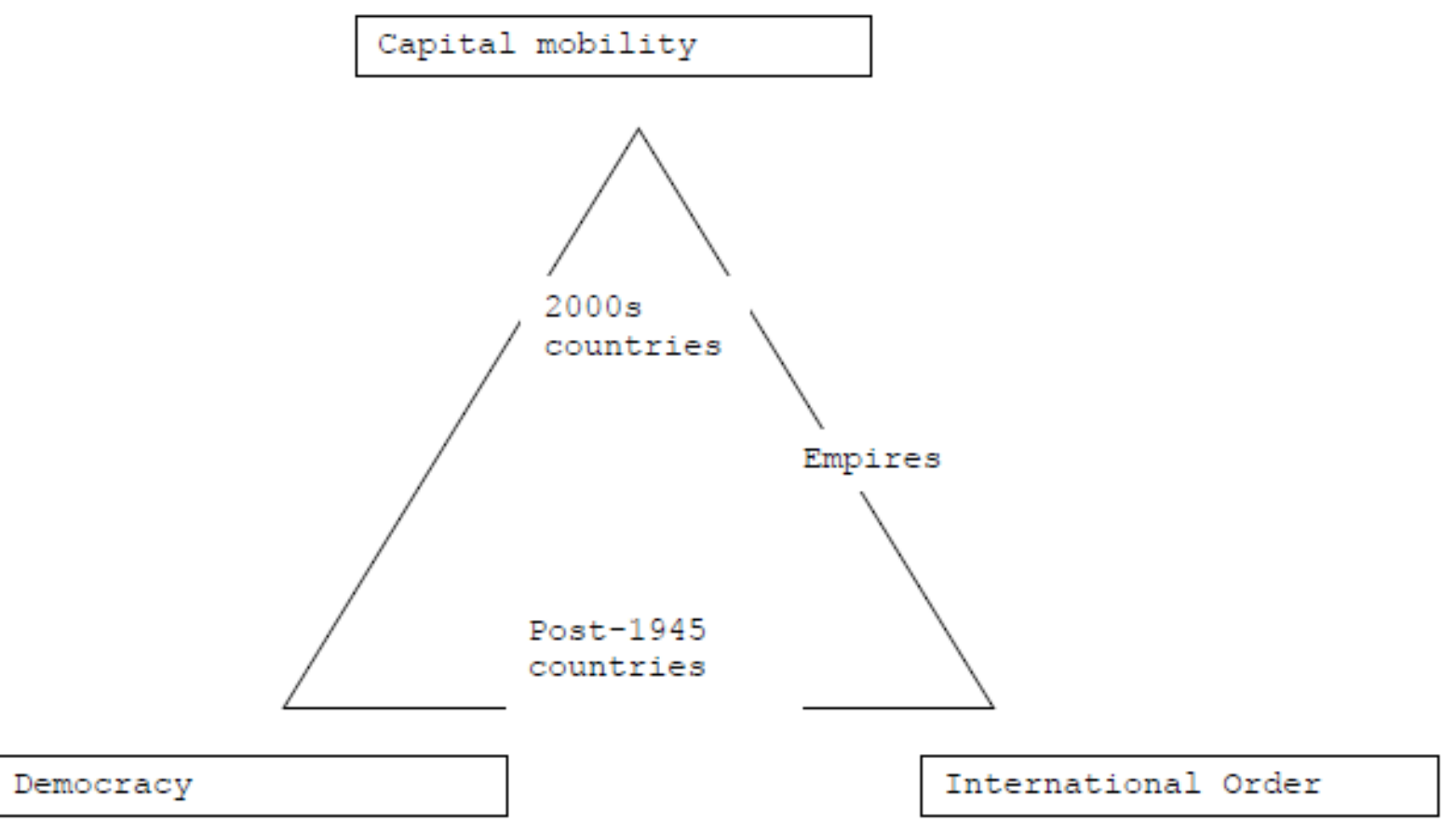

The fourth trilemma can thus be formulated: that capital flows, democracy, and a stable international political order cannot be reconciled with each other.

2 Financial Times, February 7, 2015, "An Athenian boxer fights the good fight." 
Implications

The multiple trilemmas may not pose the apparently impossible policy straitjackets which they seem to represent. In practice, there are always intermediary solutions: in the original macro-economic version, there is never pure capital mobility, or pure monetary policy autonomy. Some restrictions on capital mobility - even the home preference of investors, or increased macroprudential controls on banking - gives some room for policy maneuver. Policy-makers are always making practical trade-offs.

Such an approach also indicates how practical responses to the other three trilemmas are likely to evolve. Capital mobility is central to all the trilemmas, and so it might be tempting to recast the story in terms of a conclusion that capital mobility is simply not worth it (Stiglitz 1998, Bhagwati 2004). In practice, the historical experience shows that such a turning away from capital mobility is not that easy, and that it carries an economic and political cost. Capital mobility is constitutive of modern globalization. It is the apple in the Garden of Eden: irresistibly attractive but causing constant problems and misery. Once tasted, it is hard to spit the apple out again.

If financial stability is to be compatible with increased capital mobility, there is also a requirement for a greater level of policy coordination on financial stability issues. Since 2008, this has been a priority in international discussions in the Financial Stability Board (established in 2009 as a successor to the Financial Stability Forum in the wake of the Asia crisis). But the task of coordination is always challenged by national regulatory solutions that respond to particular local circumstances.

Absolutely irreversible fixed exchange rates - for instance in a monetary union - require some heightened degree of political coordination (if not necessarily a political union). In the nineteenth century (to 1914) the gold standard economic world co-existed with a political stability underpinned by an increasingly precarious international alliance 
system. The failure of the alliance system to contain conflict in 1914 ended the economic calculations of gold standard participants, and currency convertibility was suspended in almost every state. In the 1920s the attempt to restore the gold standard was made alongside the attempt to build order through the League of Nations. After 1945, in the Bretton Woods order, democracies were less constrained as there were effective limits on capital movements. The opening of capital markets required a greater realism on the part of participants in a democratic process.

Democratic politics will not work when too many promises are made. Realistic democracy involves a commitment to longer term sustainability. Sustainability is always threatened by rapid changes of policy or by policy inconsistency. Some commentators identify a fundamental "economic policy problem." Democratic societies find credible commitment to a long-term policy almost impossible, even if there is a broad consensus that such a long-term orientation would be desirable. Political scientists show that there are no really adequate mechanisms to reward current majorities for future economic performance that comes at a current cost and where the payoffs lie several electoral terms in the future. Some even suggest that one of the reasons that fiscal reform and consolidation may work better in the United Kingdom than in the United States is that a five-year electoral cycle gives a longer horizon than a four-year one that is punctuated by midterm elections. The difficulties lie in part in the fact that present pain and future gain have often been misused as political slogans, and there is therefore a great deal of public cynicism about them. But in part, there is only a poor and limited understanding about the relationship between present policy and future economic outcomes. A great deal of argument consequently occurs about notions of a "free lunch:" in the case of monetary policy where low interest rates are supposed to deliver greater growth, employment, and prosperity levels; or in fiscal discussions, where greater spending and larger deficits shift economies from a bad to a good equilibrium. 
Multilateral institutions can be thought of as a commitment mechanism that improves the quality of democracy by limiting the power of special interest organizations that most frequently make the appeal to an apparent free lunch, and by protecting individual rights (Keohane Macedo Moravcsik 2009). The international relations trilemma is thus potentially solvable in the same way: through the evolution of a longer term framework of stability. International commitments - the foundation of a stable international order - are often ways of locking in particular domestic settlements and ensuring a longer term framework of stability. The Bretton Woods international regime is thus often rightly regarded as a mechanism by which the United States internationalized the New Deal settlement (Ikenberry 2001).

Thinking about a broader concept of democracy in an international setting reduces the political logic of a zero-sum-game mentality in which one country's gains can only be achieved through losses imposed on with others. A larger security umbrella can therefore provide a framework for a system of rules about capital movement and a framework for stability that would limit or circumscribe the destructive capacity of capital mobility fueled credit booms.

But such grand compacts - of which the best historical example is the 1944-1945 settlement that included Bretton Woods - are hard to achieve without a substantial measure of fear. The equivalent today of the time pressure that existed at the end of the Second World War is an urgent but also uncontrollably global crisis. The sad lesson of Bretton Woods is that things need to be extremely dangerous before a political dynamic of reform develops. It may be that today's world, for all its anxieties, is simply not obviously dangerous enough and that policy-makers are too secure about the permanence of the globalization phenomenon. 


\section{REFERENCES}

Bhagwati, Jagdhish (2004). In defense of globalization, New York : Oxford University Press

Bloomfield, Arthur (1959). Monetary policy under the international gold standard, 18801914, New York: Federal Reserve Bank.

Bordo, Michael D. and Hugh Rockoff (1996). “The Gold Standard as a "Good Housekeeping Seal of Approval," The Journal of Economic History, Vol. 56, No. 2 (June), pp. $389-428$

Borchardt, Knut (1991). Perspectives on Modern German Economic History and Policy, Cambridge: Cambridge University Press

Borio, Claudio, Harold James and Hyun Song Shin (2014). The international monetary and financial system: A capital account historical perspective, BIS WP 457

Cortes Conde, Roberto (1989). Dinero, Deuda y Crisis: Evolucion Fiscal y Monetaria En La Argentina, 1862-1890, Buenos Aires: Editorial Sudamericana Instituto Torcuato Di

della Paolera, Gerardo and Alan M. Taylor (2007). Straining at the Anchor: The Argentine Currency Board and the Search for Macroeconomic Stability, 1880-1935, Chicago: University of Chicago Press.

Dooley, Michael (1992). “A Model of Crises in Emerging Markets", Economic Journal 110, pp.256-272. 
Eichengreen, Barry (1992). Golden Fetters : The Gold Standard and the Great Depression, 1919-1939, New York: Oxford University Press

Eichengreen, Barry (1996). Globalizing Capital : a History of the International Monetary System, Princeton: Princeton University Press

Ferguson, Niall (1999). The House of Rothschild: Volume 1: Money's Prophets: 1798-1848, New York: Penguin.

Ferguson, Niall \& Schularick, Moritz, 2006. "The Empire Effect: The Determinants of Country Risk in the First Age of Globalization, 1880 1913," Journal of Economic History, vol. 66(02), pages 283-312

Flandreau, Marc and Frédéric Zumer (2004), The Making of Global Capital 1880-1913, Paris: OECD Development Centre Studies

Ford, A.G. (1962), The Gold Standard 1880-1914: Britain and Argentina, Oxford: Oxford University Press

Haber, Stephen H. and Charles W. Calomiris (2014), Fragile By Design: The Political Origins Of Banking Crises And Scarce Credit, Princeton: Princeton University Press.

Ikenberry, G. John (2001). After Victory: Institutions, Strategic Restraint, and The Rebuilding of Order after Major Wars, Princeton: Princeton University Press.

Kalaitzidis, Akis (2009) Europe's Greece: A Giant in the Making, New York: PalgraveMacmillan.

Keohane, Robert O. Stephen Macedo, Andrew Moravcsik, 2009. “DemocracyEnhancing Multilateralism," International Organization 63, pp.1-31. 
Krugman,Paul (1999)." Balance Sheets, The Transfer Problem and Financial Crises" Princeton University ( mimeo)

Lynn, Matthew (2011). Bust: Greece, the Euro, and the Sovereign Debt Crisis, Hoboken, N.J.: Bloomberg Press.

Marsh, David (2011). The Euro : the Battle for the New Global Currency, New Haven: Yale University Press

Mitchener, Kris James and Marc Weidenmier (2008), “Trade and Empire.” Economic Journal 118, 1805-1834

Mundell, Robert A. (1963). "Capital mobility and stabilization policy under fixed and flexible exchange rates". Canadian Journal of Economic and Political Science 29 (4): 475-485.

Obstfeld, Maurice and Alan M. Taylor (2004), Global Capital Markets: Integration, Crisis and Growth, New York and Cambridge: Cambridge University Press, 2004

Obstfeld, Maurice and Jay C. Shambaugh and Alan M. Taylor, 2005. "The Trilemma in History: Tradeoffs Among Exchange Rates, Monetary Policies, and Capital Mobility," The Review of Economics and Statistics, MIT Press, vol. 87(3), pages 423-438, December.

Padoa-Schioppa, Tommaso (1982). "Capital Mobility: Why is the Treaty Not Implemented?" in Tommaso Padoa-Schioppa (1994) The Road to Monetary Union in Europe (Oxford: Clarendon Press), pp. 26-43.

Polanyi, Karl (1944). The Great Transformation, New York: Farrar and Rinehart. 
Rey, Helene (2013), Dilemma not Trilemma: The global financial cycle and monetary policy independence, Jackson Hole Presentation, August.

Rodrik, Dani (2000). “How Far Will International Economic Integration Go?" Journal of Economic Perspectives, Vol. 14, No. 1 (Winter), pp. 177-186

Rodrik, Dani (2007). "The Inescapable Trilemma of the World Economy," in: http://rodrik.typepad.com/dani_rodriks_weblog/2007/06/the-inescapable.html

Rodrik, Dani (2011). The Globalization Paradox: Democracy and the Future of the World Economy, New York: Norton

Schnabel, Isabel (2004): “The twin German crisis of 1931," Journal of Economic History, 64, pp. 822-871.

Schuker, Stephen (1988): “American 'reparations' to Germans, 1919-33: Implications for the Third World debt crisis", Princeton Studies in International Finance, no. 61, July.

Schularick, Moritz, and Alan M. Taylor (2012). "Credit Booms Gone Bust: Monetary Policy, Leverage Cycles, and Financial Crises, 1870-2008." American Economic Review, 102(2): 1029-61.

Siegel, Jennifer (2014). For Peace And Money : French And British Finance In The Service Of Tsars And Commissars, New York: Oxford University Press.

Stiglitz, Joseph (1998), “Boats, planes and capital flows," Financial Times, March 25

Taylor, Alan M. (2003), in (eds.) Gerardo Della Paolera, Alan M. Taylor, A new economic history of Argentina, Cambridge: Cambridge University Press. 
Wallis, John Joseph, Richard E. Sylla, and Arthur Grinath III (2004). “Sovereign Debt and Repudiation: The Emerging-Market Debt Crisis in the U.S. States, 1839-1843," NBER Working Paper No. 10753 